\title{
Results of An Elementary Course in Geography
}

\section{Philip Emerson}

To cite this article: Philip Emerson (1904) Results of An Elementary Course in Geography, Journal of Geography, 3:10, 450-454, DOI: 10.1080/00221340408985551

To link to this article: http://dx.doi.org/10.1080/00221340408985551

曲 Published online: 12 May 2008.

6 Submit your article to this journal $\pi$

LII Article views: 6

Q View related articles $\sqsubset$ 
industries of a people; that is, production, manufacture, and commerce. Furthermore, these industries in the main are very largely controlled by the conditions of geographic environment; that is, by climate and topography. These are the fundamental propositions in the study of geography and if the pupil may have forgotten everything else that he has learned in his school course, he can easily rebuild a good working knowledge of the subject upon them. Without an understanding and comprehension of these principles his knowledge of the subject is incomplete, imperfect, and fragmentary.

There remains to be considered the way in which the inculcation of these fundamental principles can best be accomplished. To comprehend them a certain maturity of mind that comes only with years is essential. The German schoolboy has this sort of knowledge because he has about four more years of work in the systematic study of geography than the American pupil. Indeed, as a rule, his knowledge of the subject much surpasses that of the American boy even in matters pertaining to the geography of the United States. The American boy closes his study of the subject usually in the ei ghth year. In many schools, notably those of New York, he quits it at the end of the seventh year, just about the time he is old enough to begin these fundamental principles. In many cases, more especially in the elaborately graded schools, the conduct of the study is bent mainly to the work of preparing for the examinations. "He studies to pass and not to know; he does pass and he does not know."

\title{
RESULTS OF AN ELEMENTARY COURSE IN GEOGRAPHY
}

\author{
BY PHILIP EMERSON \\ Principal of Cobbett School, Lynn, Mass.
}

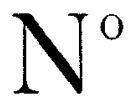

more important consideration concerning the teaching of geography exists than the question as to what results the course in this study should secure to pupils. The content of text-books and the methods chosen by the teacher are dependent upon its decision. It is fundamental to the construction of a course of study.

The graduate of a grammar school should have definite knowledge of the most important facts concerning the earth and its peoples as a result of his work in geography. Most boys and girls may forget 
the facts of mathematics they learned after the fifth or sixth grade and rarely miss the knowledge. If they fail to remember the essentials of geography presented in upper grades they are poorly prepared to read newspapers and periodical literature or to converse confidently on current events. They should be equipped with the knowledge requisite to enable them to share in the larger life and thought of their times.

In years agone, and in belated schools of both city and country extremely close to the present day, too, about the sole result of the geography course was a summary knowledge of many brief, unrelated facts as to location, products, and the like. How many capes and capitals, distant bays, and little rivers pupils pored over their maps to find! Happily, ere long most were forgottten, because, having little life importance, they were but lumber in the mind. In some school systems reaction from such teaching has resulted in a general failure to learn the locations of places having prime importance.

We may agree that a graduate should know the location of the countries of the world, perhaps a hundred of its important cities definitely and in similar manner the larger physical features and those of great influence on life, not forgetting really leading productions. Much more will be known in a rather general way, for instance that Sheffield is somewhere in the industrial district of England. The class of facts first mentioned should be so known that the pupil will habitually picture in his mind any continent and locate country, city, or river upon it so as to consider it in its true geographical relations. The ability to draw a good sketch map rapidly is proof of the mental picture and its degree of accuracy. There should be built up in a pupil's mind broad general outlines of the continents and their life, accurate so far as they go, but with no attempt to elaborate details. This latter aim would prevent accomplishing the main purpose.

But what cities and mountain ranges should be well known? some teachers ask. Why, those that the teachers themselves have found referred to again and again in papers, magazines, and books-by travelers, historians, and the commercial world. Geography studies the relations of man to his environment, and facts are important according to the closeness of their relation to man's life. There is no need that some authority should make a list of the places of first importance. Were a hundred people to make lists of the hundred cities of the world that a pupil should be able to locate closely, they would 
certainly agree in their choice of the majority. Most text-books emphasize rightly the facts of prime importance.

Geography secures to the pupil more than knowledge of mere facts; it gives knowledge of the relations, the causal connections, between facts concerning man and those as to his natural environment. A pupil should not only have knowledge of successive instances of relations between man's life and the earth; such knowledge should be organized into the more fundamental general truths of geographic relations. In this direction results are as yet unsatisfactory. The text-books state few general principles clearly; geography in its higher reaches has not been fully developed as a science. Naturally the pupil has only indefinite conceptions of the fundamental laws illustrated by the specific cases he has learned.

The relations of man to the earth have been slowly established through the changing reactions of history. These relations are often intricate and hard to comprehend. Even the simpler truths of geographic relations that are taught can be better understood, perhaps alone understood, when relations are viewed from the standpoint of their development. One result of an elementary course in geography should be some knowledge of geographic facts and relations of past time-history if you will, yet not history in its central purpose. The pupil will know the world not merely as the sum of present facts and relations, but as having developed from a different past toward a more perfect future. These larger general truths of the evolution of the relations of the different peoples to their home lands are of at least as much importance as the actual facts taught concerning present geography. When the child has become a man or woman of middle life, the facts he learned at school will have become in considerable part untrue; capitals and boundaries change, new centers of life develop, areas of production and routes of distribution wonderfully change. Principles of geographic evolution true for past development control present changes, and knowledge of such general truths of the science, geography, constitutes a guide to the understanding of current events of the world and one's home community that should be furnished in some measure to every graduate of our schools.

It is even more important that graduates should know how to study for themselves than that they know certain life facts and general truths as to their earth relations. Geography provides the earliest and best opportunity of the elementary school to train children to 
study books-both text-books and reference books. Of late it has become fashionable in some sections to cry out against slavish adherence to the text-book and to advocate the presentation of material by the teacher, who has gathered it from all sources. At its worst this is inaccurate and ineffective lecturing, a pitiable imitation of the weak feature of college methods. At its best, energetic teaching, it lacks the definiteness of result that systematic study of a text or texts secures. Although in earlier years, and in the early part of every year, new topics or sections should be introduced by class study, or discussion, of maps, pictures, and other sources of knowledge, under the teacher's active guidance, as the work proceeds and pupils perceive its spirit and methods, they should be assigned subjects for independent study, and test recitations may follow without preliminary teaching. Students may thus be trained to know how to study the pictures, maps, and text of books when they enter the secondary school or leave school for life work.

Geography affords a large and neglected opportunity for training children to use their eyes and other senses in thoughtful study of objects. Field lessons should be continued through the grades until pupils will naturally question how the human life of any newly presented community is related to its environment, even if they do not as certainly question how any new district was modeled by nature's forces. Laboratory exercises with wisely chosen and skillfully arranged sets of specimens of raw materials and finished products, whose immediate end is to enable the children to adequately understand the relations of industries, should give as much aid as nature study in developing the children's power to observe thoughtfully. Students entering the high school should know how to observe, to study the earth and objects upon it.

Pupils completing elementary work in geography should know facts and principles; should know how to gain geographic knowledge; more than this, they should know the pleasure that arises in the acquisition of knowledge of the earth and its peoples, and the inspiration to right living that may be imparted through the study of our own and other nations. A good teacher will not be satisfied with imparting and fixing certain facts and a measure of skill in their acquisition; she will earnestly desire to have every pupil close the course eager to continue his studies and fully aware of the aid that the public library affords him.

Knowledge should be so chosen and presented also as to awaken 
earnest and broad patriotism, intelligent devotion to the development of the economic and social possibilities of the home community, comprehension of the resources and relations of the nation that shall complete the work of history in securing wise citizenship, appreciation of fellow lands and peoples that shall make patriotism broad enough to know the rights of other nations and the duty of our people toward other races.

In summary: the knowledge gained during an elementary course in geography should be so limited and systematized as to be definite and permanent; it should be so gained as to open attractively a limitless field of knowledge and to inspire an earnest and practical effort to relate one's own life to its environment.

\section{FOUNDATIONAL EXPERIENCES}

BY ARTHUR P. IRVING

Buckingham School, Springfield, Mass.

\section{$\Lambda^{\mathrm{T}}$}

the opening of the last school year all of our classes took up geography work and we determined if possible to lift the study above the merely word work so of ten found. To make the study more real to the pupils was our aim.

The first step was to find out what the children offered us to build upon, not in the way of previous book knowledge but in actual observation and experiences. We also noted that ideas of the oceans, lakes, rivers, and mountains predominate in geography. Therefore we set out to learn just what the children knew at first hand of these fundamental features by having them write answers to the following questions. Some of these questions are necessarily local, covering prominent features of this section:

OCEAN-

1. Have you been on the shore of the ocean?

2. Have you tasted of the water of the ocean?

3. Have you waded into the water of the ocean?

4. Have you seen the rise and fall of the tide?

5. Have you sailed on the ocean? LAKE-

6. Have you seen a lake?

7. Name the largest lake you have seen.

8. What is the taste of lake water? 